\title{
Competing With Bitcoin - Some Policy Considerations for Issuing Digitalized Legal Tenders
}

\author{
Arto Kovanen ${ }^{1}$ \\ ${ }^{1}$ Kovanen Macroeconomic Policy Advising, L.L.C., Alexandria, USA \\ Correspondence: Arto Kovanen, Principal, Kovanen Macroeconomic Policy Advising, Alexandria, VA, USA. \\ E-mail: arto.t.kovanen@gmail.com
}

Received: October 3, 2018

Accepted: October 19, 2018

Online Published: May 6, 2019

doi:10.5430/ijfr.v10n4p1

URL: https://doi.org/10.5430/ijfr.v10n4p1

\begin{abstract}
The proliferation of peer-to-peer virtual alternatives to traditional banknotes has raised concerns among policymakers about the future of traditional means of making payments and how it might affect monetary policy implementation and its effectiveness. This study provides a brief overview of the existing research in this area. It compares positions taken in the literature by authors on some of the key policy issues relevant for central banks when thinking about the issuance of digitalized legal tenders. We examine the implications of government issued digital alternatives to traditional currencies for monetary policy effectiveness, payments and settlements, and financial market stability. We also discuss recent advances in financial technology to improve the making of payments and settlements, which might help contribute to financial inclusion. At the same time, new technologies represent challenges for regulatory authorities, for instance related to efforts to contain anti-money laundering and prevent financing of terrorism. A number of authors argue that government issued digital currency is necessary to address the flaws in private crypto currencies, and to improve monetary policy effectiveness. Central banks have begun to analyze possible features of digitalized legal tenders, to better understand the policy considerations involved and effects these could have for interest rate transmission and financial markets, but there is no clear consensus on key modalities associated with digitalized legal tenders. Moreover, many central banks do not regard privately issued virtual currencies as a serious threat to traditional currencies. Given the ongoing debate, it is difficult to make firm predictions about the impact of central bank issued digital currencies on monetary policy transmission and financial markets at this point.
\end{abstract}

Keywords: digital currencies, monetary policy effectiveness, payments and settlements, financial market stability

"Perhaps I am being short-sighted, but I find it hard to envision (except in the most abstract way) a world in which 6 billion people have accounts on a central computer and funds are transferred among them”. [Freedman (2000)]

\section{Introduction}

In a relatively short period of time, privately issued crypto currencies have gained increasing prominence around the world. Although these peer-to-peer alternatives to traditional banknotes still only account for a relatively limited portion of all financial transactions, central banks have taken notice and have started to examine whether and on what terms central banks might issue their own digital alternatives (e.g., e-dollar). Issues involved are not trivial as a number of policy and technical considerations have to be decided by policymakers. The authorities want to guarantee that privately issues crypto currencies do not undermine the integrity of regulated settlement and clearing systems and do not endanger financial stability but view risks to traditional currencies limited at the moment. Crypto currencies do not have any intrinsic value and as such are comparable to paper currencies, suggesting that they ought to be viewed as digital currencies issued by "virtual states". (Note 1) This could assist in regulating their retail trading and bring them under the regulatory frameworks applied for foreign exchange transactions, money laundering and financing of criminal activities.

This study surveys the available research on digital currencies, concentrating on central bank's role in this process while highlighting the key policy considerations for the issuer, the central bank. In particular, we examine what consequences government issued digital alternatives to traditional paper currencies might have for monetary policy effectiveness, payments and settlement systems, and financial market stability. The primary contribution of this study 
is to bring together the existing research and provide the reader an overview of the state of discussion while comparing the positions of various authors. Since the debate about the modalities of government issued digital currencies is still ongoing, it will be difficult, and perhaps not even advisable, to draw definite conclusions at this point.

Section 2 provides a short introduction to crypto currencies. It discusses recent trends in the evolving landscape for making payments with digital monies and the main characteristics of privately issued virtual currencies. This is not intended to be an exhaustive discussion of the main features of crypto currencies and how the peer-to-peer settlement systems operate, which is largely outside the scope of this paper, but it is intended to help place crypto currencies within the broader framework of payment instruments (there are several recent studies that discuss the cryptographic and economic foundations of Bitcoin and other crypto currencies, which we reference in this study). Sections 3 and 4 provide the main contributions to the paper. Section 3 surveys the existing literature and positions taken in it by authors on government issued digital currencies. We discuss some of the key characteristics of government issued digital currencies and their implications for monetary policy implementation and its effectiveness, interest rate transmission, financial markets, and settlements. There are several questions concerning government issued digital currencies that remain undecided and will have profound implications for the implementation of monetary policy and the economy, and for central bank's ability to control its balance sheet. Among the questions we will explore in this section are the following: First, should the public have a direct access to the central bank or should the distribution of digital balances be effected using digital wallets managed by private commercial banks? Second, should digital currency balances at the central bank be remunerated and what implications this would have for monetary policy implementation and financial markets? Third, what consequences a wider use of privately issued crypto currencies would have for price stability and the relevance of official legal tender as the unit of account?

Section 4 explores what implications crypto currencies have for financial markets and clearing systems. A number of authors have noted that possible applications of financial technology for clearing and settlement could significantly reduce the cost of financial transactions and provide retail users with access to a wider range of financial services, thereby encouraging financial market inclusion. At the same time, new financial technology could challenge traditional banking that depends on deposit financing while increasing risks to financial stability, as technology is likely to lower barriers to entry and reduce the cost and speed of moving assets between institutions. Moreover, crypto currencies represent a challenge to regulatory authorities, for instance by complicating the enforcement of laws on money laundering and financing of illegal activities. Section 5 offers some final thoughts.

\section{Where Do Crypto Currencies Belong in the Space of Accepted Payment Instruments?}

Since Bitcoin was introduced in 2009 as the first decentralized and peer-to-peer crypto currency (Note 2), the number of crypto currencies has grown explosively, comprising more than 1,300 as of late 2017, with a total market value of almost $\$ 600$ billion. However, the market is concentrated and dominated by a few currencies (thirty most widely used crypto currencies encompass more than 90 percent of the total market value; see Figure 1). As regards the dominance of Bitcoin, Gandal and Halaburda (2014) argue that this is due to its first-mover advantage, which is likely to diminish as other crypto currencies gain market share and receive more exposure in the media.

Features of crypto currencies vary across issued currencies, most importantly in terms of algorithms and blockchain technologies used (private crypto currencies issued since 2009 are listed in Table 1). This suggests available technology continues to evolve and no particular approach has achieved a dominant position. There are several publications that discuss the basics of crypto currencies, what types of blockchain technologies are used, and how transactions are settled, which is beyond the scope of this paper (see Mills et al. (2016) and Narayanan et al. (2016), Berentsen and Schär (2018a), Ali et al. (2014a), Andolfatto (2018), Lipton (2017), and He et al. (2016)). (Note 3) 


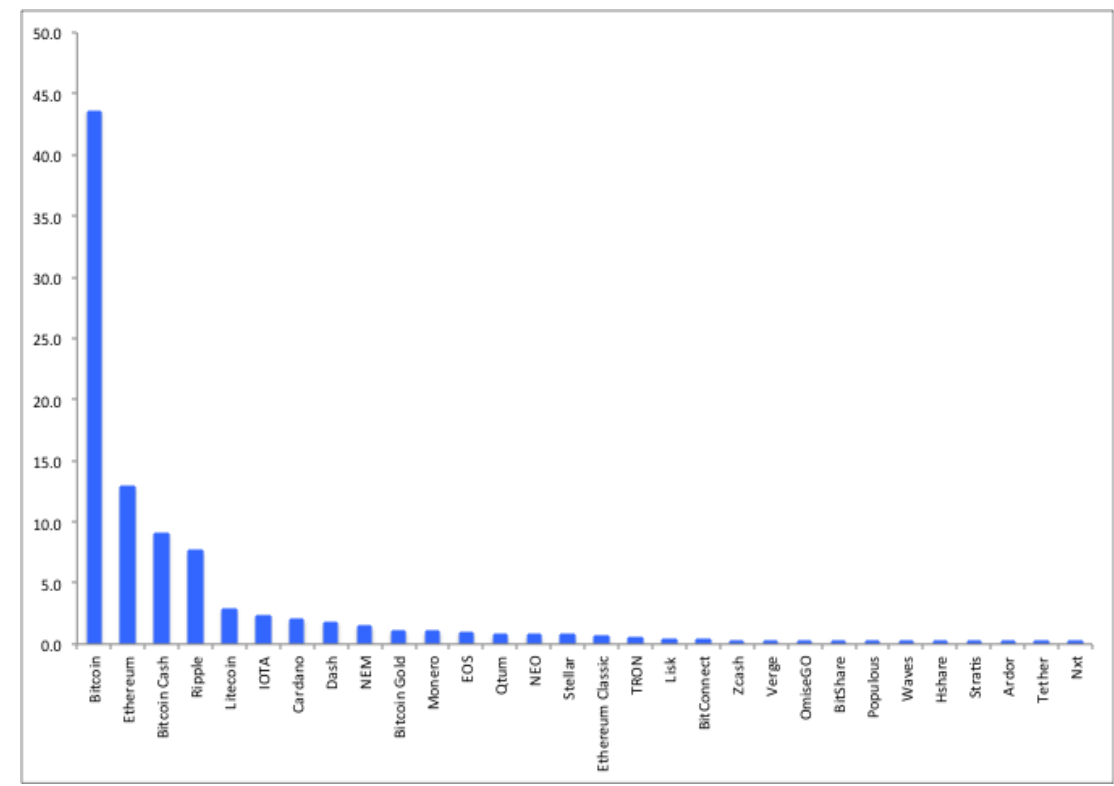

Figure 1. Largest crypto currencies by capitalization (In percent of total capitalization)

Sources: www.coinmarketcap.com and the author.

People often acquire crypto currencies through currency exchanges, which are virtual online marketplaces where sellers exchange crypto currencies against other crypto or traditional currencies (such as the U.S. dollar). Prices of crypto currencies fluctuate based on variations in supply and demand. Virtual exchanges differ in terms of the number of crypto currencies they trade, fees they charge, and regulatory requirements, among others. Trading is highly concentrated to a few exchanges, which represent roughly two-thirds of the total market value (Figure 2). (Note 4)

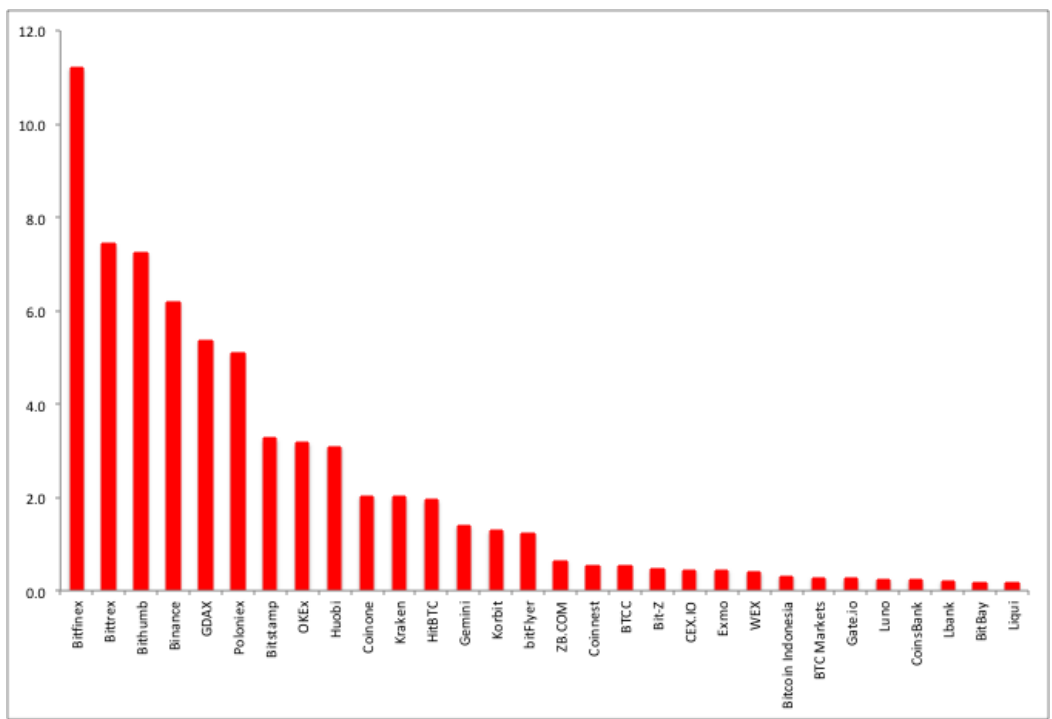

Figure 2. Largest crypto currency exchanges (In percent of total capitalization) Sources: www.coinmarketcap.com and the author. 
Table 1. List of selected crypto currencies (as of 2017)

\begin{tabular}{|c|c|c|c|c|c|}
\hline Name & Release date & Symbol & Founder & Hash algorithm & Blockchain \\
\hline Bitcoin & 2009 & BTC, XBT & Satoshi Nakamoto & SHA-256d & PoW \\
\hline Litecoin & 2011 & LTC & Charles Lee & Scrypt & PoW \\
\hline Namecoin & 2011 & NMC & Vincent Durham & SHA-256d & PoW \\
\hline SwiftCoin & 2011 & STC & & SHA-256 & PoW \\
\hline Peercoin & 2012 & PPC & $\begin{array}{l}\text { Sunny King } \\
\text { Jackson Palmer and }\end{array}$ & SHA-256d & PoW/PoS \\
\hline Dogecoin & 2013 & DOGE, XDG & $\begin{array}{l}\text { Billy Markus } \\
\text { EvgenijM86 and }\end{array}$ & Scrypt & PoW \\
\hline Emercoin & 2013 & EMC & Yitshak Dorfman & SHA-256 & PoW/PoS \\
\hline Gridcoin & 2013 & GRC & Rob Halford & Scrypt & Decentralized PoS \\
\hline Omni & 2013 & MSC & J.R. Willett & SHA-256d & N/A \\
\hline Primecoin & 2013 & XPM & $\begin{array}{l}\text { Sunny King } \\
\text { Chris Larsen and Jod }\end{array}$ & $1 \mathrm{CC} .2 \mathrm{CC} / \mathrm{TWN}$ & PoW \\
\hline Ripple & 2013 & XRP & McCaleb & ECDSA & "Consensus" \\
\hline Auroracoin & 2014 & AUR & Baldur Odinsson & Scrypt & PoW \\
\hline Blackcoin & 2014 & $\mathrm{BC}$ & Rat4 & Scrypt & PoS \\
\hline Burstcoin & 2014 & BURST & Burstcoin Community & SHA-256d & Proof of Capacity \\
\hline Coinye & 2014 & KOI, COYE & Evan Duffield and Kyle & Scrypt & $\begin{array}{l}\text { PoW } \\
\text { PoW and Proof of }\end{array}$ \\
\hline Dash & 2014 & DASH & $\begin{array}{l}\text { Hagan } \\
\text { XDN-development }\end{array}$ & $\mathrm{x} 11$ & Service \\
\hline DigitalNote & 2014 & XDN & team and dNote & CryptoNight & PoW \\
\hline MazaCoin & 2014 & MZC & BTC Oyate Initiative & SHA-256d & PoW \\
\hline Monero & 2014 & XMR & Monero Core Team & CryptoNight & PoW \\
\hline NEM & 2014 & XEN & UtopianFuture & SHA3-512 & POi \\
\hline Nxt & 2014 & NXT & $\begin{array}{l}\text { BCNext } \\
\text { Potcoin core }\end{array}$ & SHA-256d & PoS \\
\hline PotCoin & 2014 & РOT & $\begin{array}{l}\text { development team } \\
\text { Dor Konforty and Greg }\end{array}$ & Scrypt & PoS \\
\hline Synereo AMP & 2014 & AMP & $\begin{array}{l}\text { Meredith } \\
\text { Edward Mansfield and }\end{array}$ & PoS & PoS \\
\hline Titcoin & 2014 & TIT & Richard Allen & SHA-256d & PoW \\
\hline Vertcoin & 2014 & VTC & Bushido & Lyra2RE & PoW \\
\hline Ethereum & 2015 & ETH & Vitalik Burerin & Ethash & PoW \\
\hline Ethereum Classic & 2015 & ETC & $\begin{array}{l}\text { David Sonstebo, } \\
\text { Sergey Ivanchedlo, } \\
\text { Dominik Schiener and }\end{array}$ & Ethash & Directed acyclic \\
\hline IOTA & 2015 & IOT, MIOTA & Dr. Serguei Popov & SHA-3 & graph \\
\hline SixEleven & 2015 & SIL & fflo & SHA-256d & PoW \\
\hline Decred & 2016 & DCR & & Blake-256 & PoW/PoS Hybrid \\
\hline Waves Platform & 2016 & WAVES & Sasha Ivanov & PoS & PoS \\
\hline Lisk & 2016 & LSK & Max Kordek & DPoS & DPoS \\
\hline Zcash & 2016 & ZEC & Zooko Wilcox & Equihash & PoW \\
\hline Bitcoin Cash & 2017 & $\mathrm{BCH}, \mathrm{BCC}$ & & SHA-256d & PoW \\
\hline Ubiq & 2017 & UBQ & Julian Yap & Ethash & PoW \\
\hline
\end{tabular}

Sources: https://en.wikipedia.org/wiki/List_of_cryptocurrencies and the author

Badev and Chen (2014)), using publicly available transaction data, show that Bitcoin is still barely used in payments for goods and services. Less than half of all Bitcoins in circulation are used for real transactions and about half of these transactions are less than $\$ 1,000$ (most small-value transactions are related to online gambling services rather than purchases of physical goods and services). (Note 5) Árnason (2015) suggests that the demand for Bitcoins mainly arises from decentralization and anonymity, and its use in illicit transactions. People also buy Bitcoins to profit from price volatility. Because Bitcoin and other crypto currencies are decentralized, privately generated peer-to-peer payment instruments, there is no protection against lost crypto currencies (also, unlike with legal tender issued by the government, crypto currencies do not establish claims against the issuers).

Where do crypto currencies fit in the broader scope of generally accepted payment instruments? Berentsen and Schär 
(2018b) show how private crypto currencies, such as Bitcoin, could be placed in the context of a broader framework for payment mediums. They use three dimensions to characterize payment instruments: the form instrument takes (physical or virtual), who is the issuer of the instrument (government or private sector), and how payments using the instrument are handled in the settlement system (centralized or decentralized). This is illustrated in Figure 3.

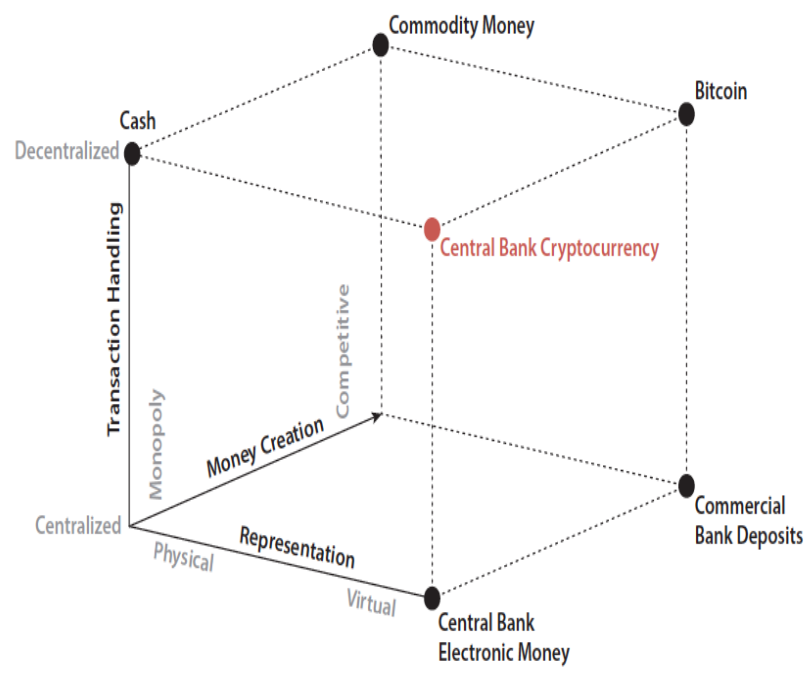

Figure 3. Alternative forms of money

Source: Berentsen and Schär (2018b)

Traditional paper currencies (fiat monies, comprising physical banknotes and coins) are issued solely by central banks. A unique feature of paper currency is its anonymity and the simplicity of ownership transfer between two entities, as cash can change hands without the involvement of a third party (the last person who holds currency becomes automatically its owner). (Note 6) An additional feature of paper currency is that it is usually the legal tender of a country, which makes it universally accepted within the borders of the country. Reserves held by commercial banks at the central bank represent another form of currency issued by the central bank. Unlike banknotes and coins, reserve balances are a form of digital currency as they are only recorded and exchanged in a digital form while access is restricted to eligible financial institutions (usually comprising deposit-taking institutions, but also some large non-banks and securities firms may have accounts at the central bank). Settlements in reserve balances are intended for large-value payments between eligible financial institutions and are channeled through centralized, regulated payment systems, which are typically operated and controlled by the central bank (e.g., real-time gross settlement systems). Furthermore, currency demand is fully accommodated, at least in the short run, and therefore changes in the currency in circulation is not considered as a monetary policy instrument, whereas altering the cost or the availability of bank reserves at the central bank represent the main channel through which monetary policy typically operates.

In modern societies, substitutes to money offered by private sector entities in digital forms try to mimic the features of paper currencies while enhancing the convenience of their usage as means of payments. In electronic money (or e-money) schemes, such as in mobile money services the link to traditional money is preserved and stored values are always expressed in the same unit of account as the legal tender (e.g., U.S. dollar). In the electronic money schemes values are stored electronically and issued against the receipt of funds of at least equal amount. (Note 7) E-money, like many other digital forms of moneys, such as credit and debit cards, or PayPal, is simply an alternative mechanism by which the public is able to interface with fiat currency (see, for instance, Bech and Garratt (2017)). (Note 8)

Crypto currencies issued by the private sector may be defined as types of unregulated, electronic payment means that are issued (and also controlled) by their developers. They are traded and accepted among the members of specific communities and exchanged outside formal financial systems. Crypto currencies differ from electronic money (e-money) schemes in that their units of account have no physical counterparts to legal tenders. (Note 9) Moreover, 
the issuer of a crypto currency is usually a non-financial entity, which means that traditional financial sector actors, such as the central bank, are not involved in the process, while financial sector regulation and supervision are not applicable. Laws do not guide any conversions between crypto and traditional currencies, and there are no fixed, one-to-one relationships between the rates of exchange, which could increase the cost of redeeming crypto funds for legal tenders (not permitted in all countries). Because crypto currencies are denominated in different units than the legal tenders, they leave control over these currencies to the issuers who govern the currency schemes and manage the supply of these currencies. (Note 10) See Bech and Garratt (2017).

Although crypto currencies try to adopt many of the features of paper currencies, they do not satisfy the key characteristics of money, at least for the time being. This makes it harder for them to function as genuine substitutes for traditional currencies, which could ease concerns among policymakers about the future of traditional means of payments. Money is thought to provide the following three basic functions: a stable unit of account, a medium of exchange, and a store of value. Because of their unstable valuations, crypto currencies have not succeeded in achieving stability of their units of account (we see this in the volatility of daily valuations of crypto currencies, which largely reflects demand volatility and inflexibility of supply). However, crypto currencies have the potential of becoming useful mediums of exchange, but for the time being only in a limited sense since these currencies are not accepted by all retailers and in some countries their use is not permitted (Ammous (2016) and Kamada (2017)). Carney (2018) and Carstens (2018) note that crypto currencies have not succeeded in becoming suitable substitutes for traditional legal tenders and they have failed to receive public trust, unlike conventional currencies issued by credible central banks. Nevertheless, these authors acknowledge that the technology behind crypto currencies (distributed ledger technology or DLT) could be useful in a number of areas. (Note 11) See also ECB (2015) and Söderberg (2018).

\section{Monetary Policy Implementation and Digital Currencies}

\subsection{E-money Schemes}

An increasing volume of retail transactions is taking place using electronic substitutes for money, which are carried out over the Internet. The rapid growth of crypto currency transactions in the U.S. and elsewhere has raised concerns about the future of government issued currencies, effectiveness of monetary policy, and central banking more broadly. These concerns, however, are not necessarily new, as the use of physical currencies for making retail payments has been dwindling for some time. Several research papers in the late 1990s and early 2000s explored these issues in the context of expanding use of electronic substitutes of traditional currencies (e-money schemes). These research papers generally concluded that interest rate control, which is the key channel for implementing monetary policy, would unlikely be lost with the increasing use of electronic payments as long as the central bank was able to control short-term interest rates. (Note 12) Increased use of netting permitted banks to substitute inside (clearinghouse) money for outside (central bank) money, and the liquidity and depth of the securities markets allowed banks to use repurchase operations with treasury bills as their primary means of liquidity management. As a result the bulk of banks' collateral base for day-to-day interbank market transactions increasingly comprised treasury bills, making these bills effectively a close substitute for settlement balances held at the central bank. Because the supply of clearinghouse money or treasury bills was not under central bank's direct control, the disappearance of monetary base (i.e., reserve balances held by banks at the central bank in particular) raised concerns among policymakers about central bank's ability to control short-term interest rates and maintain the effectiveness of monetary policy.

Henckel, Ize, and Kovanen (1999), analyzing monetary policy effectiveness in a model where central bank had no monetary liabilities (i.e., monetary base is zero as there is no currency in circulation and banks do not maintain any reserves at the central bank), showed that this did not undermine monetary control. Goodhart (2000) reinforced this point by stating that neither currency, nor central bank, was essential for the ability of the central bank to set interest rates. Because central bank is not concerned about maximizing its profits, it can always dictate the terms on either the bid or offer side of the money market. Freedman (2000) noted the importance of central bank's monopoly position in creating financial liabilities and the ability to set the rate of remuneration on excess reserve balances, which would guarantee monetary control. Friedman (2000), however, was concerned about decoupling risk due to technological innovation, which he though could undermine central bank's relevance in controlling inflation. With the electronic revolution, as Friedman put it, the demand for central bank resources could decline. (Note 13) The expansion of e-money schemes prompted King (1999) to wonder if central banks were at the peak of their influence. He also envisioned a future where settlements were carried out by the private sector without any recourse to central bank's clearing arrangements, in a sense foreseeing the emergence of privately created crypto currencies (see also Woodford (2000) and Lahdenperä (2001)). 


\subsection{Are Crypto Currencies Different?}

Crypto currencies take competition with government issued currencies to an entirely different level by offering alternative electronic payment options that were not available some two decades ago. Transactions in crypto currencies can be effected using personal computers or smart phones. Settlements may be carried out outside regulated settlement systems, relying on networks of private computers that are unregulated and unsupervised by governments. This provides convenience and privacy that cannot be match by any physical payment means. Furthermore, unlike with traditional e-money schemes mentioned in the previous section, the values of crypto currencies are not linked to the unit of legal tender, and fluctuate based on changes in demand and supply. This has the potential to decouple price formation from traditional currencies if crypto currencies become widely used. Crypto currencies therefore have the potential to profoundly undermine the demand for traditional paper currencies and their role as the standard unit of account (see discussion later). The transmission and effectiveness of monetary policy, and by extension, the future of traditional financial markets and settlement systems, could also be at risk.

This has prompted central banks to undertake studies that would help them decide whether to introduce digitalized legal tenders to complement the traditional currencies in circulation. However, many important policy questions about digital currencies and their implications remain open. They include the framework for the issuance of electronic currencies, their potential risks and implications for monetary policy and financial markets, and how to best manage these risks (see, for instance, discussion in Camera (2017)). If central banks decide to issue digitalized legal tenders, to complement traditional currencies in circulation, one of the questions of interest is whether the public should have access to the central bank and if this would involve having personal accounts at the central bank, or if the distribution of digital currency should be managed using digital wallets operated by commercial banks. There does not appear to be consensus on this issue, although it has the potential to profoundly alter the relationship between the monetary authority and the public. Another issue that needs to be considered is whether or not digital currency balances at the central bank should be remunerated (i.e., paid interest), which represent a significant deviation from the current practice where fiat money does not earn interest and most central banks do not remunerate banks' settlement balances held with them. (Note 14) Decisions on these issues would have major implications for monetary policy implementation, interest rate transmission, and the financial markets (Fung and Halaburda (2016)). (Note 15)

It is important to stress that unlike with privately issued peer-to-peer crypto currencies, central bank issued digital currencies would remain the monopoly of central banks, similar to physical paper currencies. They would also continue to trade at a fixed parity with their physical counterpart, eliminating price volatility associated with privately issued digital currencies. Settlements using digital legal tenders would be carried out using regulated payment systems, which could include the use of DLT. Unlike with privately issued crypto currencies, government issued alternatives would represent a claim against the issuer and would not have any counterparty risk (Figure 3).

A number of authors seem to favor the introduction of digitalized legal tenders. Gupta et al. (2017) suggest that it is necessary to introduce government issued digital currencies to address flaws in the privately issued crypto currencies, which include the lack of speed, price instability, limited scalability and poor security (there have been several incidents recently where the security of crypto currencies has been compromised and large amounts of privately held crypto currencies have been stolen). (Note 16) They argue that government issued crypto currency would be a superior alternative to privately issued currencies and would marginalize the use of private crypto currencies. Because of its features, government issued digital money could make physical banknotes, debit cards and other forms of electronic payment means currently offered by the private sector redundant. Similarly, Berentsen and Schär (2018b) believe that the central bank has a strong motivation to issue its legal tender in an electronic form, which would also simplify monetary policy implementation. The central bank could use the interest rate paid on private digital money accounts as a monetary policy instrument. (Note 17) Engert and Fung (2017), furthermore, emphasize that ensuring financial stability and contestability in payments could motivate the central bank to issue a digital currency, underscoring policymakers' concerns about the risks associated with proliferation of settlements effected outside regulated frameworks. However, they point out that protecting central bank seigniorage revenue and demand for settlement liquidity (issues that were discussed in the context of the e-money revolution of the late 1990s) are likely to be less important because there are alternative ways to protect central bank's revenue base (e.g., imposing fees) and the demand for reserves (e.g. requiring banks to hold statutory reserves at the central bank). (Note 18) Fernández-Villaverde and Sanches (2018) caution that purely private arrangements are unlikely to result in an efficient resource allocation, and privately issued crypto currencies are more prone to self-fulfilling inflationary episodes even when issuers are profit maximizing, long-lived firms. They show that it is possible to design a monetary policy scheme that will promote stability and efficiency even when government issued digital currency 
competes with private currencies. Moreover, privately issued digital currencies can act as a disciplinary factor for government issued digital currencies. Chiu and Koeppl (2017) stress that existing crypto currency systems do not support immediate settlement finality and therefore could result in a settlement failure (which is not the case, for instance, in government operated settlement systems, such as real-time gross settlement arrangements). They argue that privately issued crypto currencies work best when transaction volumes are large relative to the individual size of transactions (i.e., a lot of small trades).

\subsection{Policy Considerations for Issuing Digitalized Legal Tenders}

\subsubsection{Anonymity of the Ownership of Digital Currency Holders}

A key characteristic of physical banknotes is that they preserve the anonymity of the holder, which may not be important for most people but can be an attractive feature when dealing with illicit transactions. Because of the digital nature of virtual currencies, which are held on accounts, it is possible for the policymaker to monitor or shield the ownership of the government issued digital currency, similar to physical banknotes. However, its desirability is subject to a debate. Engert and Fung (2017) argue against anonymity and stress that as a technical matter it will not be feasible when the central bank pays interest on the digital currency balances (in order to pay interest on an account and report the income to the revenue authority, central bank needs to know the identities of account holders). Moreover, Berentsen and Schär (2018b) point out that anonymity could give rise to reputational risk for the central bank, which should be avoided, and Gupta (2017) underscores that "know your customer" principle should be the ethical standard for the issuance of digital currencies. See also Broadbent (2016).

\subsubsection{Granting Access to the Central Bank for Private, Non-Financial Entities}

Traditionally, only deposit-taking banks and in some cases other large non-bank financial institutions have been granted access to the central bank. Such privileged access is meant to facilitate financial institutions' daily liquidity management and enhance monetary policy implementation. In return, banks and financial institutions are often market makers for government securities. With digitalized legal tenders one issue that needs to be decided is how the digital currencies are to be distributed to the public. Unlike with paper currencies and coins, which are distributed through banks and other financial institutions, with digital legal tender it is possible to buy-pass the banking system and provide the public direct access to the central bank in the form of individual digital accounts for currency balances.

However, granting direct access to the non-financial private sector at the central bank has significant implications. Because the provision of access to the public at the central bank would profoundly alter the relationship between the monetary authority and the private sector, Ketterer and Andrade (2016) express concerns that the extension of access to individuals and companies at the central bank might unbundle the banking system. This is because the public might prefer central bank to commercial banks, as the former does not have the same default risk as private banks (i.e., risks are underwritten by the government as the owner of the central bank). Raskin and Yermack (2016) raise similar concerns and note that an interest-bearing digital currency could undermine banks' traditional sources of funding because commercial banks would lose deposits to the central bank. Barrdear and Kumhof (2016) highlight risks to the banks and the settlement systems that could arise from deposit competition between the central bank and private banks. Bordo and Levin (2017) offer a somewhat different view, believing that interest-bearing accounts at the central bank could enhance competition in the banking sector, as depositors in less competitive institutions would move their funds into risk-free accounts at the central bank. Presumably this would lead to a stronger protection of public deposits in the private banks. See Rogoff (2015) who explores the potential benefits and costs of eliminating physical banknotes.

Furthermore, Lowe (2017), Engert and Fung (2017), and Riksbank (2017), among others, citing many of the concerns discussed above, express doubt that it is in the public interest to extend access to the central bank beyond regulated financial entities. They believe that the preferred option would be to arrange the distribution of digital currencies to households and corporations through the regulated financial institutions, similar to the current arrangement for banknotes and coins. (Note 19)

\subsubsection{Remuneration of Digital Currency Balances}

Paying interest on government issued currency would be an important departure from the current practice. However, there is a trade-off that needs to be considered. First, paying interest on digital currency balances would make these balances behave more like demand deposits. They would be competing directly with similar services offered by commercial banks and place the central bank into direct competition with the commercial banks. On the other hand, offering interest on digital currency balances is thought to enhance monetary policy effectiveness because it would 
allow a direct interest rate transmission from the policy interest rate to the retail sector, instead of working through short-term money market interest rates and commercial banks' balance sheets.

For instance, BIS (2017) notes that monetary transmission would be strengthened if the central bank issued digital currency were to pay interest. A wider access to central bank digital currency could strengthen the pass-through from policy interest rates to money market and lending interest rates. Furthermore, by setting interest rates on digital currency balances, the central bank would be able to establish an effective floor on retail deposit interest rates in the economy (this would be similar to an interest rate corridor operated by many central banks in the wholesale money market, which establishes a minimum interest rate for banks' wholesale liquidity). Bordo and Levin (2017) support the establishment of interest-bearing individual accounts for digital currency balances at the central bank. They point out that paying interest on the digital currency would allow the central bank to push interest rates into negative territory, which is believed to make monetary policy more effective (see Berentsen and Schär (2018b)). Barrdear and Kumhof (2016) argue that an interest-bearing digital legal tender would offer macroeconomic advantages and would be net positive for the society, for instance by reducing transaction costs. Engert and Fung (2017), however, are concerned that an interest-bearing digital currency would fundamentally change how the financial system functions and make banks more dependent on the central bank for liquidity (due to loss of deposits).

\subsection{Impact on the Demand for Money}

A widespread use of digital currencies could lead to substitution away from traditional currencies. It could fundamentally affect the demand for central bank money and weaken the central bank's ability to maintain low and stable inflation. Ali et al. (2014b) consider such a situation unlikely, provided monetary policy remains credible, but recommend that central banks may want to prevent this by issuing their own digital currencies as alternatives to traditional banknotes. (Note 20) Heller (2017) points out that there will always be residual demand for the government issued legal tender (e.g., for illicit activities and paying taxes). (Note 21) ECB (2012) cautions that crypto currencies could impact price stability and monetary policy if their proliferation reduces the demand for central bank liabilities and interferes with the central bank's control of money supply. Pfister (2017) emphasizes that the definitions of money aggregates and reserve ratios would need to be expanded to incorporate privately issued crypto currencies into these aggregates, which in part would reconstitute central bank's control of money aggregates (see Stevens (2017), Brasad (2018), Bjerg (2017), BIS (2018), Deloitte (2015) and European Parliament (2017a and 2017b)).

Moreover, profound shifts in money demand could alter the monetary transmission process, as noted in ECB (2012)). For instance, the transfer of public deposits from commercial banks to the central bank would significantly change how banks finance their lending. Meaning et al. (2017), however, appropriately argue that the impact on the transmission mechanism remains unclear and ultimately depends on the modalities of the government issued digital currency. If bank deposits become close substitutes to the central bank's digital currency balances, the transmission from the policy rate to deposits rates could significantly change and possibly become stronger. This could have impact banks' funding costs and lending interest rates. Furthermore, a universal access to the central bank could expand the secondary market if it allows a much broader set of agents to operate in this market at more diverse terms (assuming that holders of accounts at the central bank are allowed to participate in the wholesale money market, which is not necessarily given as a result of having access to the central bank). BIS (2017) notes that DLT could impact the transmission of monetary policy by reducing banks capital charges and funding costs due to lower liquidity premium on Treasury securities. Furthermore, Ali et al. (2014b) stress that an important risk to monetary transmission (in the United Kingdom) could come from the erosion in the use of the sterling as a means of payments if the proliferation of privately issued digital currencies were to become widespread. If the sterling was only used to meet obligations to the government (e.g., to pay taxes) while other transactions were to be carried out using privately issued, peer-to-peer virtual currencies, relevance of the sterling as the unit of account could be at risk. This could undermine monetary policy effectiveness as the link between central bank's control of the cost of funds and aggregate demand disappears. See Danezis and Meiklejohn (2017), Pfister (2017) and Wandhöfer (2017).

\subsection{Unique Role of the Central Bank}

Many central banks do not consider that privately issued virtual currencies represent a threat to traditional currencies for the time being, owing to their limited use for making payments. Central banks' views on key policy issues related to the issuance of digital currencies also differ, which complicates the assessment of their effects on monetary policy implementation and financial markets. Among central banks, Sweden's central bank, the Riksbank, appears to be more advanced with its analysis into whether and on what terms it could introduce a digital complement to cash, called e-krona (Riksbank (2017)). This reflects in part the monetary authorities' concern over the rapid decline in 
currency demand in Sweden, which is one of the lowest in the world. (Note 22) Another important argument for introducing the e-krona, as mentioned in the first interim report issued by the Riksbank in September 2017, is to ensure reliability and functioning of the national payment system (see Skingsley (2016)).

The Governor of the Australian Reserve Bank, Philip Lowe, on the other hand, dismisses the urgency to introduce it own digital currency (dubbed as eAUD). He emphasizes that the future of electronic payments is likely to be driven by costs, which for privately issued crypto currencies, such as Bitcoin, remain high. Furthermore, Lowe doubts that privately issued crypto currencies can succeed; as history has demonstrated (e.g., during the free banking era in the United States; see Federal Reserve Bank of Philadelphia (2011)), such episodes often led to instability and panic, which underscores the important role of the regulator in overseeing and supervising financial markets and settlement arrangements. See Engert and Fung (2017), Cleveland (2017), Nishikata (2017), and Mersch (2017). (Note 23)

Moreover, the introduction of central bank digital currency could give rise to potential conflict of interest between the central bank and private financial institutions. This is an important issue that has received less attention than may be warranted. It arises from competition between the central bank and private sector financial institutions when central bank offers substitutes to private sector deposits, while at the same time the central bank acts as the regulator and supervisor of the private financial institutions (see, for instance, Bordo and Levin (2017), Gupta et al. (2017), Raskin and Yermack (2016), and Pfister (2017)). These authors point out that preserving the separation is essential, due to the special role the central bank has in the economy, which distinguishes it from the private financial institutions.

Unlike commercial banks and other financial institutions, central banks do not seek to maximize profits as their operations are driven by broader macroeconomic policy considerations. For instance, the Federal Reserve has a dual mandate encompassing price stability and full employment. In order to achieve these policy objectives, the Federal Reserve may at times implement monetary policy at the expense to its profitability. Moreover, by law the central bank has an exclusive right to issue the legal tender (banknotes and coins). Being "the bank of bankers", one of the most important service the central bank offers to commercial banks and other eligible financial institutions is liquidity that financial institutions can use to manage their intra-day (e.g., central banks provide intra-day liquidity through the real-time gross settlement system) and end-of-day settlements (provision of liquidity to enable banks to complete end-of-day settlements and offering banks reserve accounts to deposit surplus liquidity).

Central banks also play a critical role in overseeing and regulating payment and settlement systems. (Note 24) Riksbank's interim report (Riksbank (2017)) underscores the unique role of the central bank and its involvement with a number of functions important for financial intermediation. Some activities, such as large-value payments in the interbank market, will require settlement finality and stable value of tokens, which central banks are in a better position to guarantee. A central bank's digital token with the anonymity of a paper currency and the speed and security of high-value payment system could profoundly change the incentives of financial intermediaries. Furthermore, a credible central bank could maintain a stable value of digital tokens as part of the conduct of monetary policy while in a token-based system central bank could also control risks in the high-value payment system by legally and technically restricting which entities are allowed to directly hold tokens. (Note 25)

Greenwood-Nimmo (2009) emphasizes the regulatory challenges to the development of electronic money transfer systems, and notes that they should be addressed in a way that preserves the central bank's arms-length relationship with the non-financial retail sector. Commercial banks have the incentive to integrate forward and acquire firms with new financial technology whereas financial technology firms will have incentive to integrate backward and attempt to exploit the economics of scope by acquiring banking licenses. Aaron et al. (2017) note that a complete decentralization seems socially wasteful, which can lead to a natural role for a trusted central bank. See Fung and Halaburda (2016).

\section{Implications for Payment Systems and Financial Markets}

The potential of DLT to improve clearing, settlements and record keeping has been noted by many authors. Ali et al. (2014a), among others, argue that DLT represents a key innovation in the digital transaction technology, which will allow payment systems to operate in a decentralized manner. Brainard (2016) complements this by highlighting that innovations in financial technology have the potential to expand access to credit and other services for a wide array of consumers and businesses and reduce processing and underwriting costs. He et al. (2016) underscore the potential benefits of DLT for promoting financial inclusion, which may be particularly important for developing countries, while Mills et al. (2016) discuss the possible applications of DLT for lowering the cost of cross-border remittance payments, providing end-users with access to a wide range of financial services, and enhancing information sharing across various independent auditors and supervisors. 
Aaron et al. (2017) stress that central banks need to monitor innovations in the financial technology, provide a broader access to the infrastructures they control, and encourage testing of new business models. Furthermore, new financial technology is likely to challenge traditional banking models that rely on deposit financing by reducing barriers to entry and lowering the switching cost to customers away from traditional intermediaries. Regarding financial stability, Aaron et al. (2017) note that financial technology represents an important risk to the central bank's ability to ensure a safe and efficient financial system, as boundaries between financial intermediaries, markets, and other service providers become less clear. This will increase the premium placed on trust among networks and service providers (He et al. (2017), for instance). It will also challenge current regulatory and supervisory approaches that are typically focused on regulating specific institutions rather than specific activities. Some financial technology start-ups are investigating the possibility to establish alternative clearing and settlement systems to compete with traditional settlement arrangements, which would result in the inclusion of new entrants and change organizational boundaries. Risks to financial sector oversight could also come from the complexity of new applications. It will require that the authorities keep up with the evolving landscape. BIS (2015 and 2018) highlight that DLT could change how people access their savings and obtain credits, which could lead to a widespread substitution away from traditional currencies.

The rapid growth of privately issued decentralized crypto currencies poses important risks to efforts to contain money laundering and financing of illegal activities. Financial Action Task Force (FATF) raises concerns about the crypto currencies and their potential use by criminals, in financing terrorism and other illegal activities (FATF, 2014 and 2015). When crypto currencies can be exchanged for government issued currencies or other crypto currencies outside traditional, regulated payment systems, it creates a potential vulnerability and could give rise to money laundering and potential for terrorism financing. This risk will be more pronounced with privately issued crypto currencies, which have greater anonymity than traditional non-cash payment methods while they have a global reach through the Internet. Because crypto currencies rely on complex infrastructures that involve several entities and spread across several countries, their use makes the assignment of responsibility for compliance on anti-money laundering (AML) and countering financing of terrorism (CFT) difficult, unlike with government issued crypto currencies where AML/CFT jurisdictions are clearly defined. See He et al. (2016 and 2017) who underscore the risks arising from new technologies for AML/CFT, tax evasion, and fraud, while the authors recognize that new technology could also assist in lowering the cost of compliance with AML/CFT regulations.

\section{Final Thoughts}

The proliferation of peer-to-peer crypto currencies has caught the interest of monetary policy authorities and academics. Many central banks have started to examine whether it is necessary to issue their own digital currencies and on what terms. However, no major central bank has yet moved ahead to issue its own digital complement to banknotes and coins. Central banks' positions regarding the exact modalities of government issued digital currencies and their possible roles also differ. Many important questions about digital currencies remain undecided. This study has reviewed the available literature in this area and focused on some of the policy considerations affecting the central banks, and what implications government issued alternatives could have for monetary policy effectiveness, payments and settlements, and financial stability.

Many authors find strong arguments to support the introduction of digitalized legal tenders whereas central banks do not see an immediate need for them, as they perceive that threat from privately issued digital currencies still remains rather limited. However, it is possible that the digitalization of the U.S. dollar and currencies around the world is going to take place, perhaps in the not-so-distant future. The proliferation of privately issues, peer-to-peer crypto currencies would pressure the authorities into action and bring these currencies within formal regulatory environment. Government issued digital currencies would have legal tender status and trade at par value against their physical counterparts, unlike privately issued peer-to-peer crypto currencies, thereby offering a stable store of value that can continue to serve as a unit of account. These features, along with being a risk-free asset backed by government, would have important advantages over privately issued crypto currencies. These advantages are likely to marginalize the attractiveness of privately issued crypto currencies.

Although debate about the specific features of digitalized legal tenders is ongoing, it is likely that digital currencies issued by central banks would have features similar to their private alternatives. For instance, they could be designed in such a manner that would preserve anonymity of the holder (similar to physical banknotes), although some argue that this may not be desirable as it could exposure the central bank to reputational risk. Ledger generation could be decentralized (e.g., distributed across participating financial institutions), if necessary, but it should not rely on peer-to-peer verification by retail users through a private network of computers, as is the case with Bitcoin and other 
private crypto currencies. The generation of the currency would be centralized, similar to the current banknote issuance, where central bank will act as the sole issuer, which among other things would help standardize digital currency's features and guarantee its credibility, stability and supply. Several authors have highlighted that safeguarding financial and settlement systems stability would be an important driver for rolling out government issued digital currencies.

Existing research highlights that it is essential for the policymakers to preserve central bank's arms-length relationship with the non-financial retail sector. Permitting the public to establish accounts with the central bank is not required for the management of central bank issued digital currency and it would represent a significant departure from the current practice. Furthermore, having central bank offer close substitutes to the services provided by commercial banks and other regulated financial institutions would bring monetary authority into direct competition with these institutions and have profound implications for monetary transmission and the financial markets. Aside from the possible conflict of interest for the central bank that continues to regulate and supervise these institutions, it is likely to alter the financial landscape and impact banks' profitability.

It is broadly acknowledged that advances in financial technology could offer a huge potential to alter the way payments and settlements, as well as recordkeeping, are handled in the future. Innovations in financial technology could help expand access to credit and other financial services for a wide array of consumers and businesses, thereby promoting financial inclusion, which may be particularly promising for developing countries. At the same time, new financial technology represents a potential risk to central banks and their ability to ensure safe and efficient financial structures, while financial innovations could blur boundaries between commercial banks, financial intermediaries, markets, and service providers. Risks in this area can come also from the complexity of new applications that will require the authorities to keep up with the developments in the financial landscape. Moreover, the rapid growth of privately issued crypto currencies can represent obstacles for efforts to contain money laundering and financing of illegal activities.

\section{References}

Aaron, M., Rivadeneyra, F., \& Sohal, S. (2017, July). Fintech: Is This Time Different? A Framework for Assessing Risks and Opportunities for Central Banks. Staff Discussion Paper, 2017-10, Bank of Canada.

Ali, R., Barrdear, J., Clews, R., \& Southgate, J. (2014a). Innovations in Payment Technologies and the Emergence of Digital Currencies. Quarterly Bulletin, Quarter 3, 262-75, Bank of England.

Ali, R., Barrdear, J., Clews, R., \& Southgate, J. (2014b). The Economics of Digital Currencies. Quarterly Bulletin, Quarter 3, 276-86, Bank of England.

Ammous, S. (2016, August). Can Cryptocurrencies Fulfill the Functions of Money?. Center on Capitalism and Society, Working Paper, 92, Columbia University.

Andolfatto, D. (2018). Blockchain: What It Is, What It Does, and Why You Probably Don't Need One. Federal Reserve Bank of St. Louis Review, Second Quarter, 87-96. https://doi.org/10.20955/r.2018.87-95

Árnason, S. L. (2015, June). Cryptocurrency and Bitcoin: A Possible Foundation of Future Currency, Why It Has Value, What Is Its History, and Its Future Outlook. B. Sc. Essay in Business, University of Iceland.

Badev, A., \& Chen, M. (2014). Bitcoin: Technical Background and Data Analysis. Finance and Economics Discussion Series, 2014-104, Federal Reserve Board, Washington, D.C.

Bajpai, P. (2017, December 12). How to Invest in Bitcoin Exchange Futures. Investopedia.

Barrdear, J., \& Kumhof, M. (2016, July). The Macroeconomics of Central Bank Issued Digital Currencies. Staff Working Paper, 605, Bank of England.

Bech, M., \& Garratt, R. (2017, September). Central Bank Cryptocurrencies. Quarterly Review, BIS, 55-70.

Berentsen, A., \& Schär, F. (2018a). A Short Introduction to the World of Cryptocurrencies. Federal Reserve Bank of St. Louis Review, First Quarter, 1-16.

Berentsen, A., \& Schär, F. (2018b). The Case for Central Bank Electronic Money and the Non-Case for Central Bank Cryptocurrencies. Federal Reserve Bank of St. Louis Review, Second Quarter, 97-106.

BIS. (2015, November). Digital Currencies. Committee on Payments and Market Infrastructures.

BIS. (2018, March). Central Bank Digital Currencies. Committee on Payments and Market Infrastructures, Markets Committee. 
Bjerg, O. (2017, June). Designing New Money: The Policy Trilemma of Central Bank Digital Currency. CBS Working Paper, Copenhagen Business School.

Bordo, M. D., \& Levin, A. T. (2017, August). Central Bank Digital Currency and the Future of Monetary Policy. Hoover Institute, Stanford University.

Brainard, L. (2016, December 2). The Opportunities and Challenges of Fintech. Remarks made at the Conference on Financial Innovation at the Board of Governors of the Federal Reserve System. Washington, D.C.

Broadbent, B. (2016, March 2). Central Banks and Digital Currencies. Speech at the London School of Economics.

Camera, G. (2017). A Perspective on Electronic Alternatives to Traditional Currencies. Sveriges Riksbank Economic Review, 1, 126-148.

Carney, M. (2018, March 2). The Future of Money. Speech by Governor of the Bank of England at the Scottish Economics Conference, Edinburgh University.

Carstens, A. (2018, February 6). Money in the Digital Age: What Role for Central Banks?. Lecture at the House of Finance, Goethe University, Frankfurt.

Chiu, J., \& Koeppl, T. (2017, April). The Economics of Cryptocurrencies: Bitcoin and Beyond. Victoria University of Wellington.

Cleland, V. (2017, August 23). Digital Future for Sterling; Assessing the Implications. Global Public Investor, Official Monetary and Financial Institutions Forum.

Commodity Futures Trading Commission (CFTC). (2017, December 1). CFTC Statement on Self-Certification of Bitcoin Products by CME, CFE, and Cantor Exchange. Press Release.

Danezis, G., \& Meiklejohn, S. (2017). Centrally Banked Cryptocurrencies. University College London.

Deloitte. (2015). State-Sponsored Cryptocurrency: Adapting the Best of Bitcoin's Innovation to the Payments Ecosystem.

ECB. (2012, October). Virtual Currency Schemes.

ECB. (2015, February). Virtual Currency Schemes - A Further Analysis.

Engert, W., \& Fung, B. S.C. (2017, November). Central Bank Digital Currency: Motivation and Implications. Staff Discussion Paper, 2017-16, Bank of Canada.

European Parliament. (2017a, May). Potential Impact of Financial Innovation on Monetary Policy: In-Depth Analysis. Economic and Monetary Affairs.

European Parliament. (2017b, May). The Implications of Digital Currencies for Monetary Policy: In-Depth Analysis. Economic and Monetary Affairs.

FATF. (2014, June). Virtual Currencies: Key Definitions and Potential AML/CFT Risks.

FATF. (2015, June). Virtual Currencies: Guidance for Risk-Based Approach.

Federal Reserve Bank of Philadelphia. (2011). The State and National Banking Eras: A Chapter in the History of Central Banking.

Fernández-Villaverde, J., \& Sanches, D. (2018, February). On the Economics of Digital Currencies. Working Papers, WP 18-07, Research Department, Federal Reserve Bank of Philadelphia.

Freedman, C. (2000). Monetary Policy Implementation: Past, Present, and Future - Will the Advent of Electronic Money Lead to the Demise of Central Banking?. Bank of Canada. https://doi.org/10.3386/w8057

Friedman, B. M. (2000). Decoupling at the Margin: The Threat to Monetary Policy from the Electronic Revolution. International Finance, 3(2), 261-272. https://doi.org/10.1111/1468-2362.00051

Fung, B. S. C., \& Halaburda, H. (2016). Central Bank Digital Currencies: A Framework for Assessing Why and How. Staff Discussion Paper, 2016-22, Bank of Canada. https://doi.org/10.2139/ssrn.2994052

Gandal, N., \& Halaburda, H. (2014). Competition in the Cryptocurrency Market. Working Paper, 2014-33, Bank of Canada.

Goodhart, C. A. E. (2000, August). Can Central Bank Survive the IT Revolution?. Special Paper, 125, Financial Markets Group, an ESRC Research Centre, London School of Economics. 
Greenwood-Nimmo, M. (2009, January). Reassessing the "Threat" of E-Money: New Evidence from the Euro Area.

Gupta, S., Lauppe, P., \& Ravishankar, S. (2017, May). Fedcoin: A Blockchain-Backed Central Bank Cryptocurrency. Yale University.

He, D., Habermeier, K., Leckow, R., Haksar, V., Almeida, Y., Kashima, M., ... Verdugo-Yepes, C. (2016, January). Virtual Currencies and Beyond: Initial Considerations. Staff Discussion Note, SDN/16/03, International Monetary Fund.

He, D., Lechow, R., Haksar, V., Mancini-Griffoli, T., Jenkinson, N., Kashima, M., ... Tourpe, H. (2017, June). Fintech and Financial Services: Initial Considerations. Staff Discussion Note, SDN/17/05, International Monetary Fund.

Heller, D. (2017, April). Do Digital Currencies Pose a Threat to Sovereign Currencies and Central Banks?. Peterson Institute for International Economics, 17-13.

Henckel, T., Ize, A., \& Kovanen, A. (1999, July). Central Banking Without Central Bank Money. Working Paper, WP/99/92, International Monetary Fund.

Internal Revenue Service (IRS). (2014). Notice. N-14-21. Retrieved from www.irs.gov

Kamada, K. (2017). The Transaction Demand for Paper and Digital Currencies. Discussion Paper, 2017-E-6, Institute for Monetary and Economic Studies, Bank of Japan.

Ketterer, J. A., \& Andrade, G. (2016, April). Digital Central Bank Money and the Unbundling of the Banking Function. Discussion Paper, IDB-DP-449, Inter-American Development Bank.

King, M. (1999, August 27). Challenges for Monetary Policy: New and Old. Speech given by Deputy Governor of the Bank of England at the Symposium on "New Challenges for Monetary Policy".

Lahdenperä, H. (2001, December). Payment and Financial Innovation, Reserve Demand and the Implementation of Monetary Policy. Discussion Papers, 26, Bank of Finland.

Lipton, A. (2017, March). Blockchain and Distributed Ledgers in Retrospective and Perspective. MIT Connection Science and Engineering.

List of Cryptocurrencies. (2017). Retrieved from https://en.wikipedia.org/wiki/List_of_cryptocurrencies

Lowe, P. (2017, December 13). An eAUD. Address to the 2017 Australian Payment Summit, Sydney.

Meaning, J., Barker, J., Clayton, E., \& Dyson, B. (2017, June). Broadening Narrow Money: Monetary Policy with a Central Bank Digital Currency.

Mersch, Y. (2017, January 16). Digital Base Money: An Assessment from the European Central Bank's Perspective. Speech at the Bank of Finland.

Mills, D., Wang, K., Malone, B., Ravi, A., Marquardt, J., Chen, C., ... Baird, M. (2016). Distributed Ledger Technology in Payments, Clearing, and Settlement. Finance and Economics Discussion Series, 2016-095, Federal Reserve Board, Washington, D.C. https://doi.org/10.17016/FEDS.2016.095

Mobile Payment. (2017). Retrieved from https://en.wikipedia.org/wiki/Mobile_payment

Nakamoto, S. (2008). Bitcoin: A Peer-to-Peer Electronic Cash System.

Narayanan, A., Bonneau, J., Felten, E., Miller, A., \& Goldfeder, S. (2016). Bitcoin and Cryptocurrency Technologies: A Comprehensive Introduction. Princeton University Press.

Nishikata, T. (2017, October). Central Bank-Issued Digital Currencies: Once-In-A-Lifetime Opportunity for Next-Generation Financial System. Nomura Research Institute, Ltd.

Pfister, C. (2017, September). Monetary Policy and Digital Currencies: Much Ado About Nothing?. Working Paper, WP 642, Banque de France.

Raskin, M., \& Yermack, D. (2016, May). Digital Currencies, Decentralized Ledgers, and the Future of Central Banking. Working Paper, 22238, National Bureau of Economic Research.

Rogoff, K. (2015). Costs and Benefits to Phasing Out Paper Currency, Chapter 7. NBER Macroeconomics Annual 2014, 29, University of Chicago Press.

Rotman, S. (2014, January). Bitcoin Versus Electronic Money. Brief, Consultative Group to Assist the Poor (CGAP).

Skingsley, C. (2016, November 16). Should the Riksbank Issue E-krona?. Speech at the FinTech Stockholm 2016, 
Berns.

Söderberg, G. (2018, March 14). Are Bitcoin and Other Crypto-Assets Money?. Economic Commentaries, No. 5, Sveriges Riksbank.

Stevens, A. (2017, June). Digital Currencies: Threats and Opportunities for Monetary Policy. National Bank of Belgium Economic Review, 79-92.

Sveriges Riksbank. (2017, September). The Riksbank's E-Krona Project: Report 1.

Wandhöfer, R. (2017, October). The Future of Digital Retail Payments in Europe: A Role for Central Bank Issued Crypto Cash?.

Woodford, M. (2000, August). Monetary Policy in a World Without Money. Working Paper, 7853, National Bureau of Economic Research.

\section{Notes}

Note 1. We could think of crypto currencies as being legal tenders of virtual states. However, unlike regular countries, virtual states have no real activity and no residents. This begs the question why anyone would accept as payment an instrument that has no legal backing (e.g., gold), is not regulated, and is issued and controlled by an unknown entity (often using a pseudo name) whose reputation cannot be validated?

Note 2. See Nakamoto (2008) for a discussion about Bitcoin.

Note 3. In relation to Table 1 , Hash algorithm refers to a mathematical formula that maps data of arbitrary size to a bit string of a fixed size (a hash). Bitcoin and many other crypto currencies utilize the so-called Proof of Work (PoW) protocol, which is based on effort as a way to validate the authenticity of transactions and to create new blocks (mining Bitcoins). Alternatives include Proof of Stake (PoS), where the creator of the next block is selected based on a set of indicators reflecting the participant's stake in the system, Proof of Importance (PoI), among others, and variations of them.

Note 4. The largest virtual currency market, Bitfinex, trades 64 crypto currencies and has an average daily volume of around $\$ 5$ billion (of this Bitcoin represents one-third). The Chicago Mercantile Exchange Inc. (CME) and the CBOE Futures Exchange (CFE) started trading Bitcoin futures in December 2017 (see Bajpai (2017)). Interestingly, the U.S. Commodity Futures Trading Commission (CFTC) classified Bitcoin as a commodity rather than a currency (CFTC (2017)). Furthermore, the Internal Revenue Service (IRS) has classified crypto currencies as commodities for the federal tax purposes (IRS (2014), Notice, 2014-21). It has also stated that trades in crypto currencies are to be treated as property transactions for tax purposes.

Note 5. This is likely to be the case with other crypto currencies.

Note 6. Perhaps the most important downside of paper currency is its "carrying cost" and inconvenience it has for making large-value payments.

Note 7. E-money is not a legal tender since its acceptance is not universal and mandated by law, but arises from agreements between private parties.

Note 8 . There are a number of mobile payment services, which allow people to send e-money through their e-money accounts using mobile phones, instead of paying with cash, checks or credit cards. These are regulated by the authorities and operated by financial institutions. In developing countries mobile payment services, such as M-PESA in Kenya, have emerged as a way to extend financial services to rural areas that lack traditional banking services. Other types of mobile payment services are mobile wallets (e.g., PayPal, Amazon Payments, and Google Wallet), card-based payments, carrier billing (e.g., used when making a purchase on an e-commerce website), contract-less payments (that allow individuals to make payments at stores with smartcard) and direct transfers. See, for instance, Mobile payments (2017), and Rotman (2014).

Note 9. The unit of account of Bitcoin is BTC. Smallest unit of Bitcoin is millibitcoin (mBTC), which is 0.001 of one Bitcoin.

Note 10. For instance, Bitcoin supply is capped at 21 million units of BTC.

Note 11. Carney (2018) points out that the speed and cost of traditional payment transactions is far better than for crypto currencies, as the latter face significant capacity constraints compared to other payment systems (e.g., Visa can process up to 65 thousand transactions per second globally, whereas Bitcoin can only manage 7 transactions per 
second).

Note 12. Modern central banks conduct monetary policy through the interest rate channel rather than by attempting to achieve a particular level of reserve or broad money.

Note 13. This underscores the importance of policy credibility in monetary policy implementation. As Alan Greenspan, a former chairman of the Federal Reserve, stated some time ago, monetary policy is all about influencing public's expectations.

Note 14. Although, for instance, the U.S. Federal Reserve begun to remunerate settlement balances in the context of monetary policy implementation in the post-Global Financial Crisis era.

Note 15. In the past, a parallel discussion has involved the remuneration of banks reserve balances at the central bank. Most central banks have decided not to offer remuneration for banks' reserve balances during normal times, even when banks are required to hold reserves to meet statutory reserve requirements, both because of the cost of such operations and to discourage banks from depositing surplus funds at the central bank.

Note 16. Some of the weaknesses in Bitcoin include price volatility, anonymity, centralization of Bitcoins whereby few players with fastest mining hardware control the confirmation of transactions, and the slow processing speed (verification can take more than 10 minutes). Furthermore, the supply of Bitcoins is pre-determined (capped at 21 million units), which is likely to turn Bitcoin into an asset like gold to sit on and hoard (Gupta et al (2017)).

Note 17. It is assumed that central bank would not extend credits to private individuals and firms.

Note 18. Notwithstanding, having an adequate and stable income is important for the central bank, as loss of income to cover the cost of policy and other operations could risk central bank's policy autonomy. See Rogoff (2015).

Note 19. Designated private service providers certified or licensed by the central bank could provide digital wallets to the public.

Note 20. These effects could be much more pronounced with crypto currencies than with the proliferation of e-money schemes in the 1990s. If virtual currencies become important substitutes for traditional payment means, a significant portion of settlements could shift outside regulated systems, and boundaries between traditional banking and the non-financial sector could become blurred.

Note 21. ECB (2015) identifies a number of risks associated with privately issued digital currencies.

Note 22. The transition away from cash payments in Sweden has been particularly sharp. In the late 1980s currency in circulation accounted for about 40 percent of GDP. The use of banknotes has declined to 1-2 percent of GDP in 2016. Other Nordic countries are likely to display similar patterns.

Note 23. Moreover, Bank of England has extended access to central bank settlement accounts to nonbank payment service providers (for both e-money and payment institutions) as a means of promoting more diverse and innovative sterling payments market (see Cleveland (2017)).

Note 24. Central banks also regulate foreign exchange markets and transactions thereof, as well as offer lender-of-last resort financing for solvent institutions facing temporary liquidity pressures.

Note 25. Central banks typically restrict services to commercial banks and other financial institutions that maintain accounts with it. 